\title{
PENGEMBANGAN MEDIA PEMBELAJARAN INTERAKTIF DI TENGAH PANDEMI COVID 19
}

\author{
Syaiful Arif $^{1 *}{ }^{*}$ Ariza Rahmadana Hidayati $^{2}$ \\ 1,2 Program Studi Tadris IPA IAIN Ponorogo, Indonesia \\ *Corresponding author: syaiful@iainponorogo.ac.id
}

DOI: $10.24929 /$ lensa.v11i2.171

Received: 9 Juli 2021

Revised:30 September 2021

Accepted: 9 Oktober 2021

\begin{abstract}
ABSTRAK
Kemampuan berpikir kritis merupakan salah satu kemampuan yang diajarkan dipembelajarn IPA, hasil observasi menunjukkan nilai kemampuan berpikir kritis $\bar{X}$ 40,62 yang artinya dalam kategori rendah. Untuk meningkatkan kemampuan berpikir kritis perlu dikembangkan suatu media pembelajaran interaktif dengan menggunakan adobe flash yang terintegrasi dengan ayat ayat al-Quran. Penelitian ini bertujuan untuk membuat perangkat lunak berupa media pembelajaran interaktif, untuk meningkatkan kemampuan berpikir kritis. Metode penelitian menggunakan model R\&D. Tahapan mengembangkan media meliputi studi pendahuluan, tahapan pengembangan, validasi, revisi, uji lapangan dan produk. Pengambilan sampel menggunakan teknik random sampling dan claster random sampling. Data dikumpulkan menggunakan angket validasi dan uji coba yaitu melalui respon peserta didik. Kemudian dianalisis secara deskriptif kualitatif, kuantitatif. Berdasarkan hasil penelitian diperoleh hasil validasi ahli materi mendapatkan skor rata-rata $85,11 \%$ dengan kategori sangat valid. Hasil validasi ahli media mendapatkan skor rata-rata $84,86 \%$ dengan kategori sangat valid. Hasil uji coba produk yang dikembangkan dinyatakan praktis dengan nilai persentase sebesar $97 \%$.
\end{abstract}

Kata kunci: Media, Interaktif, Adobe flash, Pencemaran, Lingkungan, Covid 19.

\begin{abstract}
Critical thinking ability is one of the skills taught in science learning, the results of observations show the value of critical thinking ability $\bar{X} 40.62$ which means it is in the low category. To improve critical thinking skills, it is necessary to develop an interactive learning media using Adobe Flash which is integrated with the verses of the Koran. This study aims to create software in the form of interactive learning media, to improve critical thinking skills. The research method uses the R\&D model. The stages of developing the media include preliminary studies, development stages, validation, revisions, field tests and products. Sampling using random sampling technique and cluster random sampling. Data were collected using a validation questionnaire and a trial, namely through student responses. Then analyzed descriptively qualitatively, quantitatively. Based on the results of the study, the results of the validation of material experts obtained an average score of $85.11 \%$ with a very valid category. The results of media expert validation get an average score of $84.86 \%$ with a very valid category. The test results of the developed product were declared practical with a percentage value of $97 \%$.
\end{abstract}

Keywords: Media, Interactive, Adobe Flash, Pollution, Environment, Covid 19

PENDAHULUAN

Perkembangan peradaban dan kemajuan zaman di tandainya kemajuan teknologi, terutama berkembangnya teknologi informasi yang membuat semakin 
mudah mengakses informasi dengan cepat. Memasuki Masyarakat Ekonomi Asean (MEA), dituntut untuk meningkatkan kualitas Sumber Daya Manusia (SDM). Sumber daya manusia yang ada di Indonesia harus ditingkatkan agar mampu berkompetisi dan bersaing dengan tenaga kerja dari luar negeri sekalipun. Salah satu cara untuk meningkatkan kualitas SDM yaitu dengan meningkat kualitas pendidikan. Melalui peningkatan kualitas pendidikan diharapkan kan menghasilkan peserta didik yang berkompeten dan berdaya saing tinggi. Ditingkatkannya suatu kualitas pendidikan akan menghasilkan pesertadidik yang berkompeten, berkarakter, terampil dan mampu bersaing diera global saat ini. Berbagai kemampuan yang wajib dimiliki oleh peserta didik antara lain kemampuan berpikir kritis, kemampuan berpikir kreatif, kemampuan bekerjasama, dan kemampuan berkomunikasi. Kemampuan-kemampuan tersebut dapat diterapkan dan dikembangkan lewat proses pembelajaran di dalam kelas terutama pembelajaran sains/IPA. Pemahaman terkait ilmu pengetahuan dan teknologi dapat diterapkan dalam pembelajaran IPA. Sehingga melalui pembelajaran IPA diharapkan dapat mengembangkan dan meningkatkan kemampuan berpikir, rasa ingin tahu serta minat belajar siswa terhadap ilmu pengetahuan dan teknologi. Melalui pembelajaran IPA peserta didik mampu mengetahui dan mendapatkan penguasaan tentang alam semesta berupa fakta, konsep, prinsip dan teori yang dapat dikaitkan dengan kehidupan sehari-hari (Khusniati, 2012; Rosarina et al., 2016; Suryaningsih, 2017).

Pembelajaran IPA penting sekali untuk diajarkan dalam dunia pendidikan formal maupun non formal, selain dapat memajukan dan meningkatkan sumber daya manusia tetapi juga mencetak pesertadidik yang mampu berkompetisi dan berdaya saing di era global dimana harus terampil menguasai Ilmu pengetahuan dan teknologi. Di dunia pendidikan peserta didik tidak semata-mata dikembangkan kemampuan kognitif saja saja namun juga diajarkan bagaimana mengolah emosi dan mengembangkan sikap spiritul terhadap peserta didik sendiri. Dalam Standar Isi (SI) dijelaskan bahwa proses pembelajaran suatu ilmu pengetahuan dan teknologi dimasukkan ke dalam pembelajaran SMP dan SMA agar peserta didik mendapatkan kompetensi Ilmu pengetahuan dan teknologi. Sehingga peserta didik terbiasa untuk mandiri, kreatif dan berpikir kritis (Maryani \& Syamsudin, 2009; Sari \& Sugiyarto, 2015; Susilana \& Riyana, 2008). Hal tersebut sudah jelas, pembelajaran IPA merupakan pembelajaran yang sangat penting diajarkan dalam dunia pendidikan karena pembelajaran IPA adalah pembelajaran berbasis teori yang sistematis, gejalagejala alam menjadi penerapannya, observasi merupakan metode ilmiahnya, eksperiman adalah tindakan tindakannya. Kegiatan eksperimen dapat menumbuhkn sikap ilmiah melalui rasa ingin tahu, jujur, terbuka, kerjasama tanggungjawab dan lain sebagainya.

Ciri khas pembelajaran IPA antara lain yaitu dengan melakukan kerja ilmiah sehingga menuntut untuk dikembangkan suatu produk, dari dari pengemangan produk ini akan memunculkan berbagai bentuk keterampilan salahsatnya keterampilan berpikir kritis (Lestari, 2019). Ketika peserta didiksedang melaksanakan prosedur kerja yang artinya pesertadidik saat itu sedang melakukan kerja ilmiah dan melatih keterampilan kerja. Dalam kegiatan bekerja berupa mengamati atau menyelidiki selanjutnya diolah dalam bentuk grafik atau tabel, dari situlah setidaknya peserta didik sudah dapat melakukan keterampilan berpikir kritis. Kemampuan berpikir kritis sangat diperlukan dalam perkembangan kehidupan hingga seseorang sudah terlepas dari bangku sekolah (Karim \& Normaya, 2015; Mumtahanah, 2013). Memiliki kemampuan berpikir kritis berpengaruh sekali terhadap kehidupan seseorang karena kemampuan berpikir kritis mampu mendewasakan seseorang dalam bersikap dalam membuat keputusan yang akan digunakan banyak orang. Berpikir kritis sebagai arah untuk meraih kesuksesan di era global ini. Elemen terpenting dalam pembelajaran IPA adalah mampu menghasilkan produk dari suatu proses, sehingga hal itu dapat memunculkan kemampuan berpikir kritis peserta didik. Seseorang mempuyai kemampuan berpikir kritis dapat mempengaruhi kehidupan dirinya di masa yang akan datang terutama erat kaitannya seseorang mampu mengambil suatu 
keputusan dengan bijak dan adil., dengan demikian kemampuan berpikir kritis dapat dijadikan modal untuk kesuksesan diabad 21 atau eraglobal saat ini.

Kondisi sekarang ini dunia tengah diguncangkan dengan suatu wabah, yaitu Covid 19. Sumber penularan wabah ini belum diketahui dengan pasti, akan tetapi kasus pertama kali muncul di kaitkan dengan pasar ikan di di daerah Wuhan (Susilo et al., 2020). Pertama kali penyakit ini disebut novel corona virus (2019nCoV), tepatnya pada tanggal 11 Februari 2020 badan organisasi dunia WHO mengumumkan nama baru Corona Virus Dsease (COVID-19) (Isbaniah \& Susanto, 2020; Susilo et al., 2020). Virus ini dapat ditularkan dari manusia ke manusia lain dengan cepat. Karena penyebaran virus sangat cepat hingga memakan korban manusia di dunia sangat banyak.

Covid 19 dilaporkan pertama kalidi Indonesia pada tanggal 2 Maret 2020 sejumlah dua kasus (Abdi, 2020). Hingga pada tanggal 31 Maret 2020 kasus terkonfirmasi sebanyak 1.525 orang dan 136 jiwa dinyatakan telah meninggal. Tingkat mortalitas di Indonesia sebesar 8,9\% merupakan yang tertinggi di Asia Tenggara (Apriluana \& Fikawati, 2018; Syahria et al., 2015). Dengan banyaknya memakan korban, akibatnya berbagai negara berusaha untuk memutus rantai penyebaran, salah satunya di Indonesia memberikan kebijakan physical distancing yang juga berdampak pada dunia pendidikan.

Dunia pendidikan di Indonesia tengah memberlakukan kebijakan meliburkan sekolah dengan mengganti kegiatan proses belajar mengajar (KBM) dengan memanfaatkan dalam jaringan (daring). Selama pelaksanaan pembelajaran Online mulai bermunculan berbagai masalah yang dihadapi pesertadidik maupun guru, seperti materi pembelajaran yang dijelaskan terkadang peserta didik masih kurang faham dan juga materi pelajaran belum selesai disampaikan oleh guru kemudian guru menggantinya dengan tugas lainnya. Berbagai macam kejadian diatas mejadi keluhan peserta didik untuk saat ini. Sehingga dapat difahami bahwa dalam situasi sekarang ini karena wabah Covid 19 media dengan menggunakan adobe flash diharapkan dapat membantu peserta didik dalam belajar online dirumah. Selain mempermudah untuk menyampaikan informasi yaitu materi dan juga dapat mempermudah pemahaman peserta didik terkait materi pelajaran.

Kecanggihan teknologi merubah sistem pendidikan secara menyeluruh. Dimana media seperti televisi, radio, internet, dan juga buku memiliki potensi kepada masyarakat agar dapat kembang tumbuh. Oleh karena itu dalam kegiatan proses pembelajaran tidak mungkin mengabaikan penggunaan media. Dalam pelaksanaan pembelajaran, media pembelajaran merupakan sarana untuk menymaikan pesan dari sumber ke penerima pesan dalam hal ini yaitu guru kepada penerima pesan yaitu peserta didik. Macam-macam media yang digunakan dalam menunjang proses pembelajaran seperti saat ini yaitu buku, powerpoint, alat peraga, internet dan juga media dengan menggunakan salah satunya adobe flash.

Media pembelajaran untuk pelajaran IPA sangatlah penting. Seperti halnya penggunaan media dengan menggunakan adobe flash yang membantu menarik peserta didik untuk merangsang pikiran, perhatian, hingga kemauan pesertadidik sehingga menimbulkan terjadinya proses belajar pada pesertadidik (Kartikasari \& Rahmawati, 2018). Tidak hanya itu dalam pembuatan media dengan menggunakan adobe flash berhasil diterapkan dengan penunjang fitur-fitur yang dapat melatih peserta didik untuk berfikir serta dengan adanya fitur ayatisasi didalam materi juga dapat memberikan motivasi agar memiliki kecerdasan spiritual yang baik. Dari penggunaan media tersebut diharapkan peserta didik dapat menggunakannya dengan baik agar dapat mewujudkan tujuan dari pendidikan itu sendiri.

Kemampuan berpikir kritis terjadi di SMP Ma'arif 1 Ponorogo. Hasil temuan diantaranya yaitu proses pembelajaran masih berpusat pada guru yaitu ceramah dan terkadang praktikum. Masalah-masalah tersebut dapat diidentifikasi penyebabnya yaitu guru lebih sering mengginakan metode ceramah dalam proses pembelajaran, media yang digunakan dalam proses pembelajaran sebelumnya hanyalah powerpoint dimana penjelasannya didominasi oleh materi yang padat dan sumber belajar yang digunakan guru hanya buku paket. Dalam pembelajaran berlangsung peserta didik 
tidak hanya menerima materi saja tetapi juga diharapkan kritis terhadap materi atau persoalan yang diberikan oleh pendidik. Dalam masa pandemi Covid 19 saat ini peserta didik lebih dituntut untuk belajar mandiri dengan adanya bantuan media seperti adobe flash ini memudahkan peserta didik mandiri dalam proses belajar berlangsung dan kritis terhadap fitur-fitur, teks, audio dan animasi yang telah ditampilkan didalam media tersebut. Hasil observasi selama pengamatan pada indikator kemampuan berpikir kritis yaitu didapatkan hasil pada aspek interpretasi dalam kriteria kurang sebesar 47,91 47,91. Pada aspek analisis dalam kategori kurang yaitu 38,54. Sedangkan aspek evaluasi dalam kategori kurang yaitu 39,58 dan yang terakhir pada aspek inferensi dalam kategori rendah yaitu 36,45. Rata-rata dari semua soal menunjukkan kemampuan berpikir kritis siswa adalah 40,62 artinya kemampuan berpikir kritis menunjukkan kategori rendah. Berbeda dan sangat kurang dari target pencapaianya kriteria ketuntasan minimal yang ditetapkan oleh sekolah sebesar 75.

Media pembelajaran yang dikembangkan sangat sesuai untuk kebutuhan pembelajaran dimasa pandemi saat ini, mengingat peserta didik tidak dapat bertemu langsung dengan guru sebagai pendamping belajar setidaknya dengan media pembelajan ini peserta didik bisa memanfaatkan media untuk sumberbelajar yang sewaktu waktu bisa diakses kembali. Media adobe flash yang dikembangkan terintegrasi dengan ayat ayat al Quran sebagai petunjuk dan pegangan ummat Islam. Potongan ayat al-Quran yang digunakan senada dengan lembaga pendidikan yang dijadikan tempat belajar peserta didik, dengan mengutip potongan ayat ayat al quran menunjukkan khasanah ke ilmuan semuanya ada di dalam al-quran.

Mengingat begitu pentingnya kemampuan berpikir kritis peserta didik dan masih terbatasnya media yang bisa dimanfatkan oleh guru selama pembelajaran di masa pandemi, oleh karena media pebelajaran menjadi salah satu alternatif yang dapat dikembangkan dan digunakan untuk meningkatkan kemampuan berpikir kritis. Seorang pendidik pada jaman yang berbasis teknologi dan informasi saat ini dituntut untuk mampu membuat media pembelajaran yang inovatif guna tercapainya tujuan pembelajaran dan terwujudnya tuhuan pendidikan.

\section{METODE}

Pengambilan data dilaksanakan di SMP Ma'arif 1 Ponorogo yang beralamatkan di Jl. Batoro Katong No 13, Krajan, Cokromenggalan, Ponorogo. Penelitian ini menggunakan model Reseach and Development (R \& D) (Sugiyono, 2014). Populasi penelitian ini adalah seluruh peserta didik kelas VII SMP Negeri 2 Jetis tahun pelajaran $2019 / 2020$ yang terdiri atas dua kelas yaitu kelas D dan F. Pengambilan sampel penelitian dengan teknik random sampling pada tahap uji coba dan claster random sampling pada uji lapangan luas yaitu kelas VII D sebagai kelas eksperimen dan VII F kelas kontrol. Data dikumpulkan dengan menggunakan angket validasi dan uji coba yaitu melalui respon peserta didik.

Tahapan dan prosedur dalam pengembangan media meliputi: 1) Studi pendahuluan, kegiatan ini meliputi studi pustaka/literatur, penelitian awal/pra lapangan mencakup analisis kebutuhan, potensi masalah, karakteristik pesertadidik, kondisi lingkungan sekolah, 2) Tahapan pengembangan, pada tahap ini peneliti menyusun rancangan draf awal berupa naskah dialog, praproduksi. Setelah semua tahapan pengembangan selesai di teruskan dengan validasi kepada para ahli dalam hal ini meliputi ahli media pembelajaran, dan ahli materi pembelajaran. Setelah validasi dilakukan dan mendapatkan masukan serta saran perbaikan dari para ahli, dilakukan proses revisi produk agar kualitas produk layak untuk diujicobakan, kegiatan selanjutnya adalah ujicoba terbatas pada produk media audio visual dapat digunakan dan layak dijadikan sebagai media pendukung selama proses pembelajaran, tahap 3) Tahapan akhir berupa pengujian produk, tahap ini meliputi uji coba secara luas. 


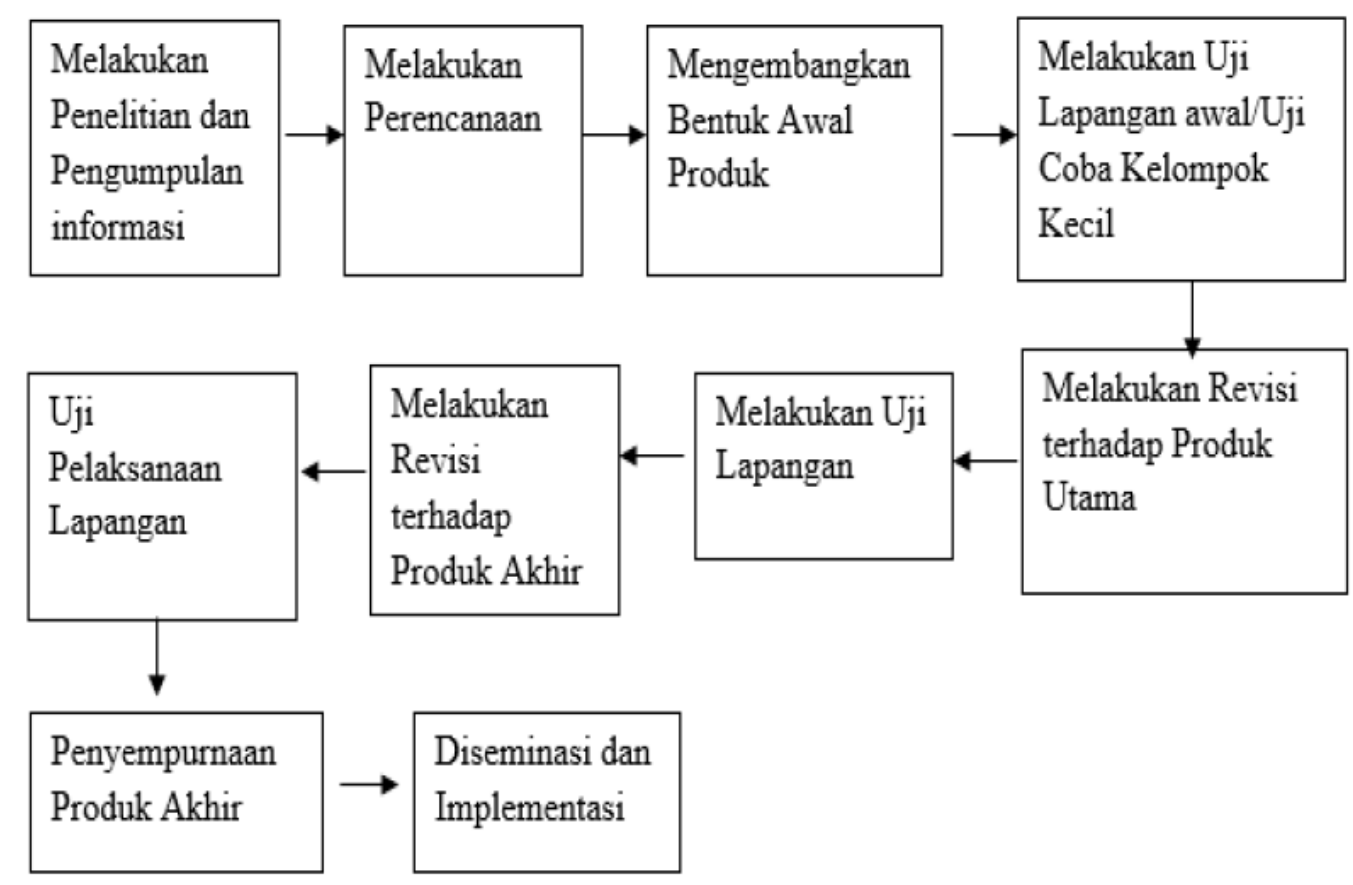

Gambar 1. Skema Tahapan Penelitian Borg and Gall

\section{HASIL DAN PEMBAHASAN}

Penelitian pengembangn yang dilakukan berupa produk pembelajaran interaktif menggunakan adobe flash dengan tahapan penelitian mengikuti Borg and Gall (Suci Rockyane \& Sukartiningsih, 2018) Penelitian pengembangan ini telah dilakukan dengan beberapa tahapan dalam menghasilkan produk pengembangan yang dapat berguna untuk meningkatkan kemampuan berpikir kritis peserta didik. Adapun langkah-langkah yang dilaksanakan peneliti dalam mengembangkan produk adalah sebagai berikut: a) Studi Pendahuluan, b) tahapan pengembangan, c) validasi, d) revisi, e) lapangan dan f) produk .

\section{A. Tahap Pendahuluan}

Berdasarkan hasil dan pengamatan lapangan di SMP Maarif 1 Ponorogo menujukkan bahwa rata-rata kemampuan berpikir pesertadidik antara lain: Aspek kemampuan berpikir kritis menggunakan tabel 45,72, aspek interpretasi 47,91, pada aspek analisis 38,54, aspek evaluasisejumlah 39,58 dan yang terakhir aspek inferensi yaitu 36,45 . Adapun perolehan rata-rata skor kemampuan berpikir kritis pesertadidik diperoleh 40,62 dimana masih rendah jika dibandingkan dengan skor KKM sekolah yang ditetapkan yaitu 75 .

Temuan tersebut mengindikasikan bahwa untuk mengembangkan kemampuan kemampuan berpikir kritis yaitu selain memperhatikan model pembelajaran yang digunakan tetapi juga mempertimbangkan media yang digunakan. Karena dengan adanya media yang aktif maupun interaktif siswa menjadi terpacu dan penasaran sehingga membuat terjadinya semangat belajar menjadi meningkat. Kristanto (2011-2018) mengemukakan dengan adanya media pembelajaran yang keseluruhannya dapat dimitasikan seperti didengar, dilihat, atau melalui oral issue memungkinkan peserta didik akan penasaran dan merangsang otak, motivasi, perhatian dalam pembelajaran untuk mencapai suatu tujuan pembelajaran.

\section{B. Tahap Pengembangan Produk}

\section{Draf Produk}

Draf produk pada penelitian ini adalah draf berupa media pembelajaran interaktif menggunakan adobe flash pada materi pencemaran lingkungan 
untuk siswa di SMP Ma'arif 1 Ponorogo. Desain produk berupa media pembelajaran interaktif.

2. Validasi

Dalam penelitian dan pengembangan pengujian instrument secara umum menggunakan pengujian validasi dan reliabilitas. Dalam validasi terdapat dua jenis yaitu validasi konstruk dan validasi isi.

Validasi konstruk yaitu penilaian validitas terkait kebenaran dari suatu item yang diukur berdasarkan pola keterkaitan antar item pertanyaan yang mengukurnya. Jadi yang dimakut item pertanyaan yaitu item yang bersifat korelasi yaitu factor utama sebagai tolak ukur dalam validasi instrument.

Sedangkan validasi isi yaitu validasi isi/materi suatu produk yang sudah dikembangkan yang instrumennya disiapkan peneliti dalam bentuk tes, validator membandingkan antara produk berupa media yang sudah dikembangkan dengan dengan instrumen yang sudah disiapkan. Jadi yang dimaksut validasi ini merupakan pengujian hasil belajar pada kemampuan ataupun keterampilan. Validasi konstruk di lakukan oleh dosen ahli dibidang pembelajaran IPA di ligkungan iain Ponorogo, berbeda dengan uji validasi isi dilakukan oleh dua dosen yang sudah doctoral sesuai dengan lingkung bidang yang diteliti. Secara teknis pengujian validitas konstruk dan validitas isi dapat menggunakn kisi-kisi instrumen atau matrik pengembangan instrumen. Penguji validasi dipilih orang yang berkompeten dalam teknologi dan IPA yaitu dosen IAIN Ponorogo.

Kegiatan validasi bertujuan untuk mengumpulkan data sebagai dasar produk berupa media pembelajaran interaktif agar layak dan bisa diujicobakan dlam proses pembelajaran sehingga dapat menunjang tujuan pembelajaran. Validasi media pembelajaran interaktif ini meliputi validasi ahli konten dan validasi ahli kontruk. Dalam validasi ahli konten dan ahli kontruk yaitu dosen IAIN Ponorogo.

3. Prototype

Setelah melalui validasi oleh ahli, kegiatan selanjutnya perbaikan. Jika produk belum sesuai dengan kriteria yang sudah ditentukan maka perlu adanya perbaikan berdasarkan masukan dan saran dari validator ahli. Namun jika produk dinilai telah baik maka proses selanjutnya pengembangan media meningkat ke tahap selanjutnya.

4. Uji 1

Uji 1 produk dalam pengembangan ini dilakukan bertujuan untuk memperoleh data dalam menentukan tingkat kevalidan pengembangan media pembelajaran, sehingga dapat diketahui dan digunakan sebagai dasar menetapkan keefektifan dan efisiensi dari produk yang dihasilkan. Uji 1 dilakukan secara terbatas kepada siswa SMP kelas VII.

5. Produk Final

Produk final dari proses pengembangan media tersebut yaitu berupa $C D$. Dengan nama CD media pembelajaran interaktif untuk materi pencemaran lingkungan kelas VII SMP. Dengan media interaktif membantu peserta didik dalam memahami konsep dan kemampuan berpikir kritis.

\section{Validasi}

Produk yang dikembangkan telah mencapai tahap finalisasi selanjutnya diberikan kepada satu validator ahli materi untuk diperlihatkan dan validitas materi yang termuat dalam media pembelajaran. Validator ahli isi/materi terdiri dari satu dosen dari prodi Tadris Ilmu Pengetahuan Alam (IPA) Institut Agama Islam Negeri Ponorogo. Validator mengisi lembar validasi isi/ konten berupa daftar checklist dalam bentuk Skala Likert yang telah disiapkan oleh peniliti (2015). Dalam validasi isi/materi menilai beberapa aspek meliputi aspek kurikulum, aspek isi, aspek bahasa dan aspek kemutakhiran materi. Pengambilan data validasi isi/materi media pembelajaran interaktif menggunakan adobe flash ini dilakukan pada tanggal 17 Februari 2020 sampai 21 Februari 2020. 
Validator mengisi lembar validasi isi/ konten berupa daftar checklist dalam bentuk Skala Likert yang telah disiapkan oleh peniliti. Dalam validasi isi menilai beberapa aspek yaitu aspek kurikulum, aspek isi, aspek bahasa dan aspek kemutakhiran materi. Penilaian yang terhadap media pembelajaran yang sudah dikembangkan menggunakan adobe flash hasil nilai rata-rata semua aspek penilaian dapat dilihat di gambar 2 sebagai berikut.

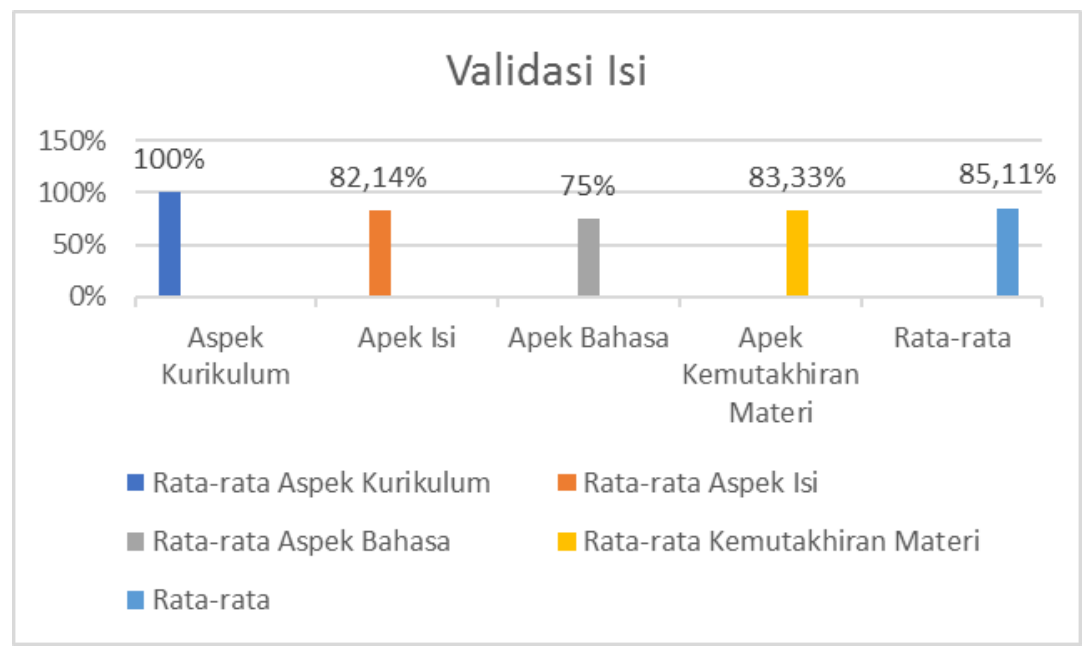

Gambar 2. Hasil Validasi Media Pembelajaran Oleh Ahli Materi

Berdasarkan Gambar 2. menunjukkan bahwa semua aspek diperoleh nilai rata-rata validasi sebesar $85,11 \%$ dengan kategori sangat valid. Perolehantersebut merupakan nilai gabungan dari rata-rata hasil rating validasi ahli materi pada aspek kurikulum sejumlah $100 \%$, aspek isi sebesar $82,14 \%$, aspek bahasa sebesar $75 \%$ dan aspek kemutakhiran matari sebesar $83,33 \%$.

Dari validasi ahli materi produk yang sudah dikembangkan diperoleh data secara kualitatif berbentuk saran dan masukan serta masukan dari validator, saran dan perbaikan oleh peneliti dapat ditampilkan sebagai berikut.

Tabel 1. Komentar dan Saran Validator terhadap Isi/ Konten

\begin{tabular}{|c|c|}
\hline $\begin{array}{c}\text { Validator } \\
\end{array}$ & Komentar dan saran \\
\hline $\begin{array}{l}\text { Muhammad Khoirul Anwar, } \\
\text { M.Pd. }\end{array}$ & $\begin{array}{l}\text { a. Perbaikan pada konsep } \\
\text { pencemaran, khusunya pada } \\
\text { arti pencemaran lingkungan. }\end{array}$ \\
\hline & $\begin{array}{l}\text { b. Perbaikan pada dampak } \\
\text { pencemaran dan upaya } \\
\text { pencegahan }\end{array}$ \\
\hline & $\begin{array}{l}\text { c. Perbaikan penempatan tanda } \\
\text { baca dan huruf kapital }\end{array}$ \\
\hline
\end{tabular}

Berdasarkan tabel kritik dan saran validator dari dosen Tadris IPA IAIN Ponorogo yaitu Muhammad Khorul Anwar, M.Pd, selain memiliki kelebihan, tetapi juga memiliki kekurangan dari media pembelajaran yang dikembangkan maka dari itu perlu diperbaiki berdasarkan perbaikan yang telah disarankan pada produk media pembelajaran. Perbaikan ini mengharuskan adanya revisi dibeberapa aspek sebagai upaya menyempurnakan produk yang sudah dikembangkan sehingga dapat digunakan oleh pesertadidik. Aspek yang perlu diperbaiki berdasarkan saran dan masukan oleh validator ahli materi terangkum dalam penjelasan gambar 3 berikut. 

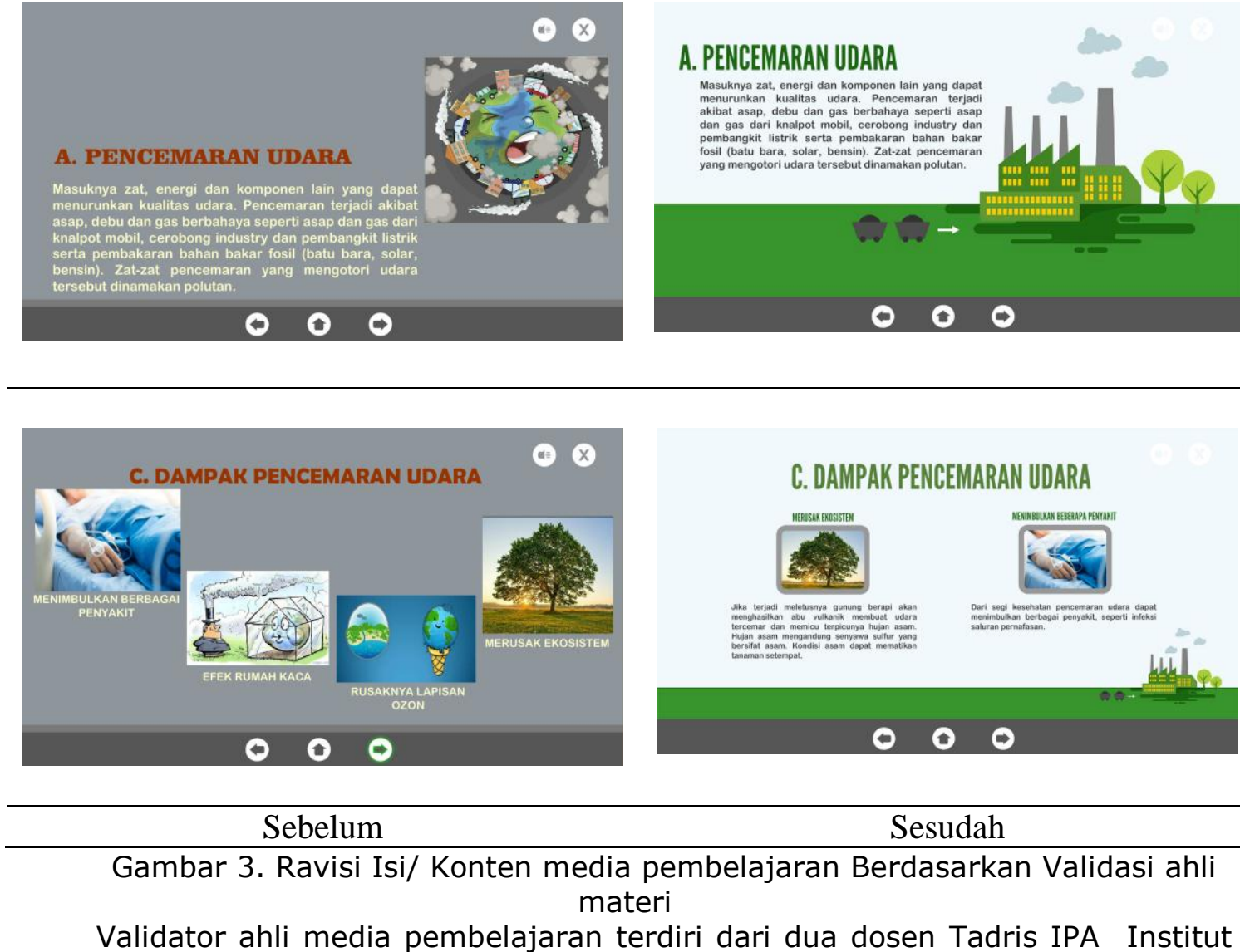

\section{Sebelum}

Sesudah

Gambar 3. Ravisi Isi/ Konten media pembelajaran Berdasarkan Validasi ahli materi

Validator ahli media pembelajaran terdiri dari dua dosen Tadris IPA Institut Agama Islam Negeri (IAIN) Ponorogo. Validator mengisi lembar validasi konstruk/ media berupa daftar checklist dalam bentuk Skala Likert yang telah disiapkan oleh peniliti. Dalam validasi konstruk menilai beberapa aspek yaitu aspek kualitas teknik, aspek kemudahan pengoperasian/ penggunaan dan aspek pemanfaatan. Hasil penilaian oleh validator ahli media pembelajaran interaktif menggunakan adobe flash dapat dibandingkan nilai rerata semua aspek pada gambar 4 sebagaiberikut.

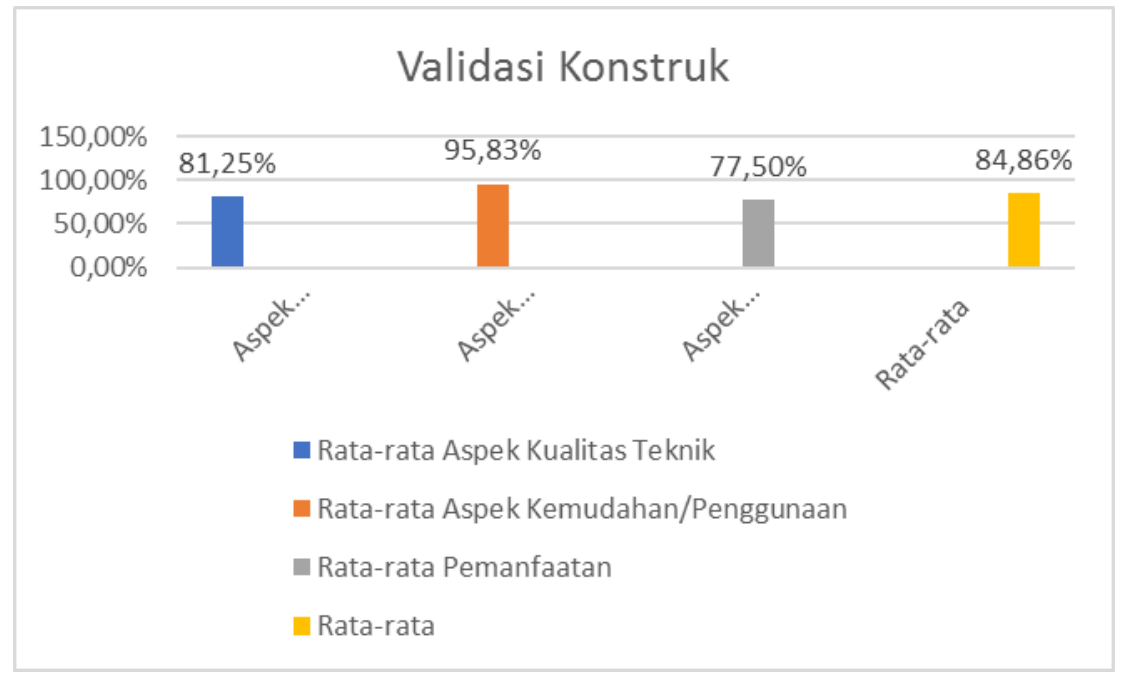

Gambar 4. Hasil validasioleh ahli media pembelajaran

Berdasarkan gambar 4. menunjukkan bahwa semua aspek diperoleh ratarata rating validasi sebesar $84,86 \%$ dengan kategori sangat valid. \%. Hasil tersebut merupakan gabungan dari rata-rata hasil rating validasi media pada 
aspek kualitas teknik sebesar 81,25\%, aspek kemudahan pengoperasian/penggunaan sebesar $95,83 \%$ dan aspek pemanfaatan sebesar $77,5 \%$.

Dari validasi konstruk diperoleh data secara kualitatif berupa komentar dan saran oleh validator ahli. Hasil berupa saran dan masukan dari validator ahli materi dapat dijabarkan sebagaiberikut.

Tabel 2. Komentar dan saran validator terhadap Konstruk/ Media

\begin{tabular}{|c|c|}
\hline Validator & Komentar dan saran \\
\hline Rahmi Faradisya Ekapti, M.Pd. & $\begin{array}{l}\text { - Ada tambahan untuk awal } \\
\text { materi yaitu pengantar materi. } \\
\text { Perbaikan beberapa kalimat. } \\
\text { Penambahan glosarium dan } \\
\text { daftar pustaka setelah selesai } \\
\text { guna peserta didik } \\
\text { mengetahui sumber belajar } \\
\text { atau materi. Dalam soal } \\
\text { latihan terdapat beberapa soal } \\
\text { perbaikan. Yang lainnya sudah } \\
\text { ok! }\end{array}$ \\
\hline $\begin{array}{l}\text { Aldila Candra Kusumaningrum, } \\
\text { M.Pd. }\end{array}$ & $\begin{array}{l}\text { - Perbaikan jenis ukuran fonts } \\
\text { dengan menggunakan } \\
\text { maksimal } 3 \text { jenis } \\
\text { - Perbaikan tampilan gambar } \\
\text { dalam materi } \\
\text { - Untuk fitur terkait berpikir } \\
\text { kritis perlu diperbaiki lagi } \\
\text { agar kemampuan berpikir } \\
\text { kritis siswa lebih terfalitasi. }\end{array}$ \\
\hline
\end{tabular}

Berdasarkan tabel kritik dan saran validator dari dosen Tadris IPA IAIN Ponorogo yaitu Rahmi Faradisya Ekapti, M.Pd dan Aldila Candra Kusumaningrum, M.Pd terdapat banyak revisi guna menyempurnakan produk yang dikembangkan. Perbaikan ini mengharuskan adanya revisi dibeberapa aspek sebagai upaya menyempurnakan produk yang telah dikembangkan sehingga dapat digunakan oleh pesertadidik. Aspek yang perlu diperbaiki berdasarkan saran validator ahli materi dapat terangkum dalam gambar 5 .
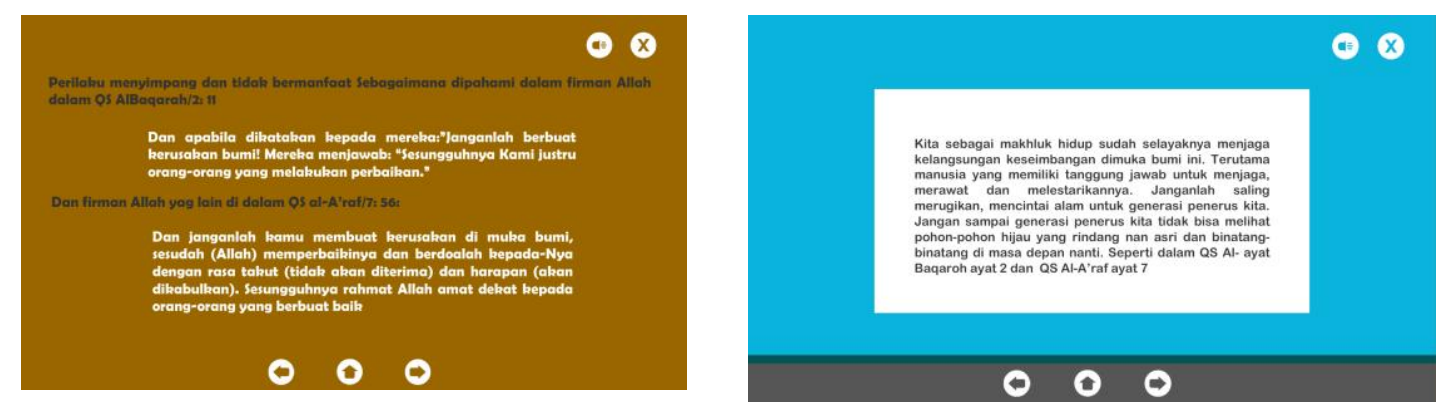

\begin{tabular}{cc}
\hline Sebelum & Sesudah \\
\hline
\end{tabular}



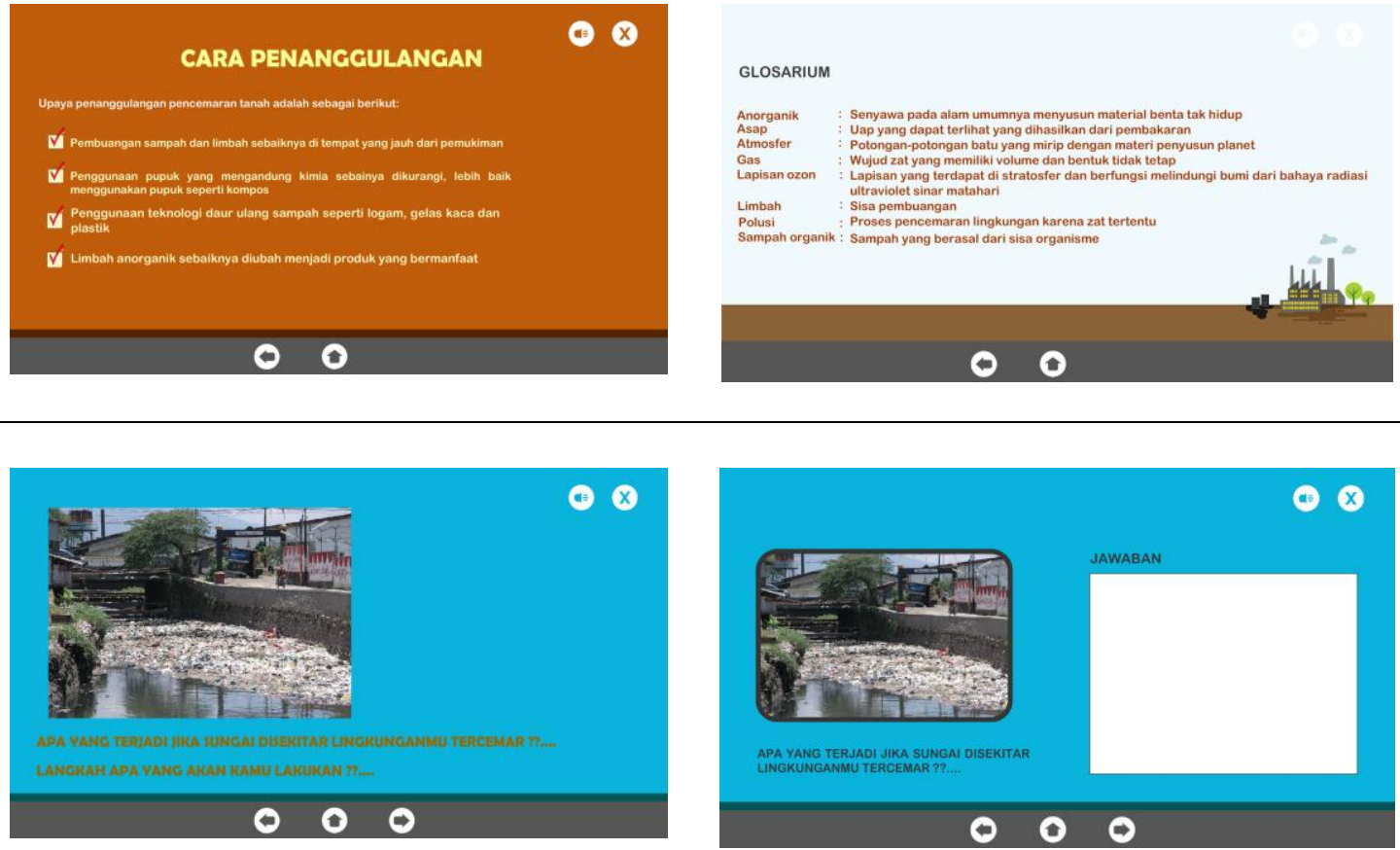

Sebelum

Sesudah

Gambar 5. Ravisi Konstruk Media Pembelajaran Berdasarkan Validasi Ahli Media

\section{Kepraktisan media pembelajaranmenggunakan adobe flash}

Kepraktisan suatu media pembelajaran dapat dilihat dari hasil ujicoba instrumen yang sudah dilaksanakan. Ujicoba secara luas bertujuan untuk untuk melihat kepraktisan dari produk yang sudah dibuat. Uji coba dilakukan setelah peserta didik menggunakan media pembelajaran interaktif yang digunakan dengan adobe flash. Dalam kegiatan uji coba peserta didik diberikan angket untuk diisi terkait respon media yang telah dikembangkan oleh peneliti dengan hasil sebagai berikut.

Tabel 3. Data Respon Peserta Didik

\begin{tabular}{|c|c|c|c|c|c|c|}
\hline No & Aspek & Pernyataan & $\begin{array}{l}\text { Sangat } \\
\text { setuju }\end{array}$ & Setuju & $\begin{array}{l}\text { Kurang } \\
\text { setuju }\end{array}$ & $\begin{array}{l}\text { Tidak } \\
\text { setuju }\end{array}$ \\
\hline \multirow[t]{6}{*}{1.} & \multirow[t]{6}{*}{$\begin{array}{l}\text { Kualitas } \\
\text { teknis }\end{array}$} & $\begin{array}{l}\text { Kemenarikan bahan ajar } \\
\text { media interaktif dalam } \\
\text { belajar }\end{array}$ & 8 & 12 & 0 & 0 \\
\hline & & $\begin{array}{l}\text { Kemenarikan desain } \\
\text { tampilan yang } \\
\text { digunakan }\end{array}$ & 10 & 10 & 0 & 0 \\
\hline & & $\begin{array}{l}\text { Kemenarikan gambar } \\
\text { yang ditampilkan }\end{array}$ & 11 & 9 & 0 & 0 \\
\hline & & $\begin{array}{l}\text { Kejelasan tulisan dalam } \\
\text { bahan ajar media } \\
\text { interaktif }\end{array}$ & 7 & 12 & 1 & 0 \\
\hline & & $\begin{array}{l}\text { Gambar dan animasi } \\
\text { yang diberikan } \\
\text { mempermudah saya } \\
\text { untuk memahami } \\
\text { materi }\end{array}$ & 11 & 8 & 1 & 0 \\
\hline & & $\begin{array}{l}\text { Kemenarikan dalam } \\
\text { menggunakan } \\
\text { komposisi warna dalam }\end{array}$ & 7 & 13 & 0 & 0 \\
\hline
\end{tabular}




\begin{tabular}{|c|c|c|c|c|c|c|}
\hline No & Aspek & Pernyataan & $\begin{array}{l}\text { Sangat } \\
\text { setuju }\end{array}$ & Setuju & $\begin{array}{l}\text { Kurang } \\
\text { setuju }\end{array}$ & $\begin{array}{c}\text { Tidak } \\
\text { setuju }\end{array}$ \\
\hline & & \multicolumn{5}{|l|}{ tampilan } \\
\hline & & $\begin{array}{l}\text { Kemudahan } \\
\text { pengoperasian bahan } \\
\text { ajar yang } \\
\text { dikembangkan }\end{array}$ & 1 & 19 & 0 & 0 \\
\hline \multicolumn{3}{|c|}{ Jumlah Siswa (100\%) } & $39 \%$ & $59 \%$ & $2 \%$ & $0 \%$ \\
\hline \multirow[t]{4}{*}{2.} & \multirow{3}{*}{$\begin{array}{l}\text { Kualitas } \\
\text { pembela } \\
\text { jaran }\end{array}$} & $\begin{array}{l}\text { Kejelasan dalam } \\
\text { memahami materi }\end{array}$ & 6 & 14 & 0 & 0 \\
\hline & & $\begin{array}{l}\text { Dengan menggunakan } \\
\text { media pembelajaran } \\
\text { interaktif dapat } \\
\text { memotivasi belajar saya }\end{array}$ & 5 & 15 & 0 & 0 \\
\hline & & $\begin{array}{l}\text { Keefektifan media } \\
\text { pembelajaran interaktif } \\
\text { dalam belajar }\end{array}$ & 5 & 15 & 0 & 0 \\
\hline & \multicolumn{2}{|c|}{ Jumlah Siswa $(100 \%)$} & $27 \%$ & $73 \%$ & $0 \%$ & $0 \%$ \\
\hline \multirow[t]{5}{*}{3.} & \multirow{5}{*}{$\begin{array}{l}\text { Aspek } \\
\text { Kelayaka } \\
\text { n } \\
\text { Penyajia } \\
\text { n }\end{array}$} & $\begin{array}{l}\text { Bahasa yang digunakan } \\
\text { baik sehingga mudah } \\
\text { dimengerti }\end{array}$ & 15 & 5 & 0 & 0 \\
\hline & & $\begin{array}{l}\text { Media yang digunakan } \\
\text { dan sederhana }\end{array}$ & 2 & 16 & 2 & 0 \\
\hline & & $\begin{array}{l}\text { Di dalam penyajiannya } \\
\text { terdapat petunjuk } \\
\text { penggunaan secara } \\
\text { singkat, jelas dan } \\
\text { lengkap }\end{array}$ & 14 & 5 & 1 & 0 \\
\hline & & $\begin{array}{l}\text { Penyajian materi dalam } \\
\text { media pembelajaran ini } \\
\text { mendorong saya untuk } \\
\text { berdiskusi dengan } \\
\text { teman }\end{array}$ & 12 & 6 & 2 & 0 \\
\hline & & lah Siswa (100\%) & $54 \%$ & $40 \%$ & $6 \%$ & $0 \%$ \\
\hline
\end{tabular}

Tabel 4. Distribusi Frekuensi Respon Siswa

\begin{tabular}{ccc}
\hline Pernyataan Peserta Didik & Persentase & Tingkat Kepraktisan \\
\hline 3 dan 4 & $97 \%$ & Praktis \\
\hline 2 dan 1 & $3 \%$ & Tidak Praktis \\
\hline
\end{tabular}

Berdasarkan data tersebut dapat diketahui bahwa hasil respon peserta didik terkait kepraktisan produk berupa media pembelajaran interaktif dengan menggunakan adobe fash sebesar $97 \%$ dinyatakan praktis dan sebanyak 3\% dinyatakan tidak praktis. Jadi dari 21 responden kebanyakan menyatakan praktis dalam penggunaan produk yang dikembangkan.

\section{KESIMPULAN}

Dari hasil penelitian yang telah dilakukan produk yang sudah dikembangkan berbentuk media pembelajaran interaktif menggunakan adobe flash yang sudah divalidasi dari segi materi dan media didapatkan, validasi ahlimateri memperoleh skor rata rata $85,11 \%$ yang termasuk kategori sangat valid. Hasil validasi ahli media pembelajaran mendapatkan skor rata-rata $84,86 \%$ yang artinya mendapatkan kategori sangat valid. Hasil respon peserta didik terkait kepraktisan produk media pembelajaran interaktif menggunakan adobe flash sebesar $97 \%$ dinyatakan praktis dan sebanyak $3 \%$ dinyatakan tidak praktis. 


\section{DAFTAR PUSTAKA}

Abdi, M. N. (2020). Krisis Ekonomi Global dari Dampak Penyebaran Virus Corona (Covid-19). AkMen Jurnal IImiah, 17(1), 90-98.

Apriluana, G., \& Fikawati, S. (2018). Analisis Faktor-Faktor Risiko terhadap Kejadian Stunting pada Balita (0-59 Bulan) di Negara Berkembang dan Asia Tenggara. Media Penelitian Dan Pengembangan Kesehatan, 28(4), 247-256.

Isbaniah, F., \& Susanto, A. D. (2020). Pneumonia Corona Virus Infection Disease-19 (COVID-19). Journal Of The Indonesian Medical Association, 70(4), 87-94.

Karim, K., \& Normaya, N. (2015). Kemampuan Berpikir Kritis Siswa dalam Pembelajaran dalam Pembelajaran Matematika dengan Menggunakan Model Jucama di Sekolah Menengah Pertama. EDU-MAT: Jurnal Pendidikan Matematika, 3(1).

Kartikasari, A., \& Rahmawati, I. (2018). Pengembangan Media Game Moou Train Berbasis Android pada Mata Pelajaran Matematika Materi Perkalian untuk Siswa Kelas III SD. Jurnal Penelitian Pendidikan Guru Sekolah Dasar, 6(2).

Khusniati, M. (2012). Pendidikan Karakter Melalui Pembelajaran IPA. Jurnal Pendidikan IPA Indonesia, 1(2).

Lestari, W. P. (2019). Studi Pendahuluan: Pembelajaran Berbasis Local Wisdom disertai Strategi Integrated Science untuk Melatihkan Keterampilan Berpikir Kritis IPA Siswa SMP. ScienceEdu, 15-23.

Maryani, E., \& Syamsudin, H. (2009). Pengembangan Program Pembelajaran IPS untuk meningkatkan kompetensi Keterampilan sosial. Jurnal Penelitian, 9(1).

Mumtahanah, N. (2013). Meningkatkan Kemampuan Berpikir Kritis Siswa Melalui Metode Cooperative Learning dalam Pembelajaran PAI. Al Hikmah: Jurnal Studi Keislaman, 3(4).

Riduwan. (2015). Skala Pengukuran Variabel-Variabel Penelitian. Alfabeta.

Rosarina, G., Sudin, A., \& Sujana, A. (2016). Penerapan model discovery learning untuk meningkatkan hasil belajar siswa pada materi perubahan wujud benda. Jurnal Pena IImiah, 1(1).

Sari, D. S., \& Sugiyarto, K. H. (2015). Pengembangan multimedia berbasis masalah untuk meningkatkan motivasi belajar dan kemampuan berpikir kritis siswa. Jurnal Inovasi Pendidikan IPA, 1(2), 153-166.

SUCI ROCKYANE, I., \& Sukartiningsih, W. (2018). Pengembangan Media Pembelajaran Interaktif Menggunakan Adobe Flash Dalam Pembelajaran Menulis Cerita Siswa Kelas IV SD. Jurnal Penelitian Pendidikan Guru Sekolah Dasar, 6(5).

Sugiyono. (2014). Metode Penelitian Pendidikan Kuantitatif, Kualitatif, dan R\&D. Alfabeta. 
Suryaningsih, Y. (2017). Pembelajaran berbasis praktikum sebagai sarana siswa untuk berlatih menerapkan keterampilan proses sains dalam materi biologi. BIO EDUCATIO:(The Journal of Science and Biology Education), 2(2).

Susilana, R., \& Riyana, C. (2008). Media pembelajaran: Hakikat, pengembangan, pemanfaatan, dan penilaian. CV. Wacana Prima.

Susilo, A., Rumende, C. M., Pitoyo, C. W., Santoso, W. D., Yulianti, M., Herikurniawan, H., Sinto, R., Singh, G., Nainggolan, L., \& Nelwan, E. J. (2020). Coronavirus Disease 2019: Tinjauan Literatur Terkini. Jurnal Penyakit Dalam Indonesia, $7(1), 45-67$.

Syahria, D. F., Kaunang, W. J., \& Ottay, R. I. (2015). Pemetaan Penyebaran Penyakit Demam Berdarah Dengue Dengan Geographic Information System Di Minahasa Selatan. Jurnal Kedokteran Komunitas Dan Tropik, 3(2). 